\section{Immunoexpression of Cathepsin D in primary and recidivant meningiomas}

Vukasinovic Bokun Zorana ${ }^{1}$, Berisavac Iva², Benovic Radomir ${ }^{2}$, Lavrnic Milica ${ }^{1}$

${ }^{1}$ Department of Pathology, Clinical Hospital Center Zemun-Belgrade

${ }^{2}$ Department of Neurosurgery, Clinical Hospital Center

Zemun-Belgrade

\section{Abstract}

The present study was performed to establish the socioepidemiological caracteristics (mean age, male to female ratio), the prevalence of various histological types of meningiomas in the groups of primary and recidivant tumors as well as Cathepsin D immunoexpression. We analysed 50 patients with primary and recidivant intracranial and intraspinal meningiomas who underwent surgery in KBC Zemun during the year 2004, with a two years follow-up. All surgical specimen were evaluated for histologic type of tumor and representative slides were immunostained with the anti-Cathepsin D antibody. In both primary and recidivant meningioma groups the number of mitosis, as factor tumor agressivness, was counted on 10 and $20 \mathrm{HPF}$ and those results were statistically analyzed. A considerable difference was found when the number of mitosis and the histologic tumor grade have been compared with the Cathepsin $\mathrm{D}$ immunoexpression. The result lead to conlusion that the immunopositivity of Cathepsin D decreases with higher mitosis count and higher tumor grade.

Key words: primary meningioma, recidivant meningioma, mitosis, Cathepsin D.

\section{Imunoekspresija Katepsina D kod primarnih i recidivantnih meningeoma}

\author{
Vukašinović Bokun Zorana ${ }^{1}$, Berisavac $\mathrm{Iva}^{2}$, \\ Benović Radomir ${ }^{2}$, Lavrnić Milica ${ }^{1}$ \\ ${ }^{1}$ Služba kliničke patologije, Kliničko bolnički centar Zemun, \\ Beograd, Srbija \\ ${ }^{2}$ Služba neurohirurgije, Kliničko bolnički centar Zemun, \\ Beograd, Srbija
}

\section{Apstrakt}

Ova studija je izvedena zbog utvrđivanja socioepidemioloških karakteristika (srednja starost, odnos muškaraca i žena), prevalence različitih histoloških tipova meningeoma u grupi primarnih i recidivantnih tumora kao i Katepsin D imunoekspresije. Analizirali smo 50 pacijenata sa primarnim i recidivantnim, intrakranijalnim i intraspinalnim meningeomima koji su operisani u KBC Zemun-Beograd u toku 2004. godine, sa dve godine praćenja. Svi hirurški uzorci su bili procenjeni kao adekvatan histološki tip, a reprezentativni preseci su imuno-obojeni sa anti-Katepsin D antitelima. Kod oba tipa, primarnog i recidivantnog meningeoma, broj mitoza, kao faktor agresivnosti tumora, brojan je na uveličanjima 10x i 20x ( HPF), i ti rezultati su statistički obrađeni. Značajna razlika je utvrđena kada je broj mitoza i histološki gradus tumara upoređen sa Katepsin D imunoekspresijom. Rezultati su doveli do zaključka da sa većim brojem mitoza i višim histološkim gradusom tumora, imunopozitivnost Katepsina D opada.

Ključne reči: primarni i recidivantni meningeom, broj mitoza, Katepsin D

\title{
Introduction
}

Meningiomas are mostly benign nonglial tumors arising from arachnoidal cap cells of the brain and spinal coverings. They rappresent $30 \%$ of all primary brain tumors with an annual incidence of 4,5/100000 individuals 1. Meningiomas tend to be numerous in the advanced age groups with a female prevalence of $2: 1$. Spinal cord meningiomas show an even higher female to male prevalence $(10: 1)^{2}$. Interestingly, agressive and invasive forms of these tumors are more often found among males and children, besides their low pevalence in these groups .Meningiomas are slow growing tumors with increased intracranial pressure symptoms at presentation (headache, seizures, focal visual loss), allthoug signs of the disease dipend on their primary localization ${ }^{1}$.

According to the WHO histological classification, meningiomas can be divided into three categories. The WHO grade I meningiomas are benign, usual non recurrent neoplasms with various histologic appearances. Atypical meningiomas (WHO grade II) are more pleomorfic neoplasms with a higher tendency to invade the brain and to recurre. The WHO grade III tumors are malignant neoplasms that show increased cellular 
abnormalities, tend to invade the microenvironment and metastasize to distant sites ${ }^{3}$. The incidence of recidiving tumors in this group is higher than in the former two groups. The most probable reason for tumor recurrence of the benign meningiomas (WHO grade I) is incomplete resection during surgery but atypical and malignant meningiomas (WHO groups II and III) tend to occur with a higer frequency even after a radical operation $^{4}$. Several studies point out that tumor invasion and infiltration of the surrounding brain tissue are the critical steps in determination of the biological behaviour of meningiomas. Invasion of tumor cells begins with adhesion to benign cells in proximity or adhesion to extracellular matrix proteins. Subsequently, there is degradation of extracellular matrix protein which is considered to be a critical step in local tumor invasion. One of the enzimes responsible for degradation of matrix protein is a lysosomal cistein peptidase Cathepsin $\mathrm{D}^{5}$. Since members of the same enzime family cathepsin B and L are involved in tumor invasion and infiltration, Cathepsin D also could play a role in the biological behaviour of agressive meningiomas, not only by degrading extracelular matrix but also by influencing tumor cell proliferation as well as tumor angiogenesis, indipendently of its proteolitical activity. A "wild" type od Cathepsin D has been demonstrated on the rat tumor cells 3Y1-Ad 12.Only this wild enzime type inhibits tumor cell apoptosis contrary to nonmutated cathepsins, so it has been stated that Cathepsin D could exibit a protective activity against tumor cell apoptosis ${ }^{6}$.

Cathepsin D activity in intracranial tumor has not been a subject of many articles. The results of these studies differ from each other and are rather controversial, but several authors agree that Cathepsin D is overexpressed in benign meningiomas. As the tumor grade rises, the expression of Cathepsin D decreases ${ }^{5,7,8}$. The usefulness of this statment lays in the fact that targeted molecular therapy can be developped to prevent the loss of Cathepsin D activity in benigni meningiomas ${ }^{5}$.

Mitogenic activity of Cathepsin D in tumor cells has been thoroughly studied in relation with breast carcinoma but a similar role in meningioma is yet to be established ${ }^{7}$.

The aims of this study were to establish the socioepidemiological caracteristics of 50 meningioma patients treated at the Neurosurgery department of the Clinical Hospital Center Zemun, Belgrade as well as the histologic types of primary and recidivant tumors. We also analized the patterns of immunoexpression of Cathepsin $\mathrm{D}$ in relation with the tumor grade and agressivness.

\section{Materials and methods}

In our study, surgical specimen and complete medical documentation from 50 patients having primary and recidivant meningioma and who underwent surgical treatment during the year 2004.were used. We included patients having only meningiomas and no other benign or malignant neoplasms. A 2 year follow-up was performed. The complete medical documentation of those patients was available and so was the individual consent for the study. A two year period of follow-up was arranged. The surgical material was formalin fixed, paraffin-embedded and H\&E slide were analized under 10x, 20x and 40x. One representative slide from each tumor was chosen for immunohistochemistry analysis. The tumors were graded according to the $2000 \mathrm{WHO}$ classification. We estimated 15 criteria for meningioma grading (hypercellularity, nuclear atypia, nuclear hyperchromasia, small or prominent nucleoli, vesicular nuclei, mitoses on 10 and $20 \mathrm{HPF}$, small cells, clear cells, rhabdoid cells, papillary formations, endothelial proliferations, histologicaly established local brain invasion, focal or confluent necrosis).All the above mentioned criteria were scored in a semiquantitative way except for the mitosis count which was graded in groups (0-4, 5-10, 11-20 and $>20)$. Recurrence free interval was defined as the period of time between the operation and the CT or MRI confirmation of an evident recidive. These data were analized using descriptive statistics and the relationship of the mitosis count and tumor grade was analized with the Mann Whitney nonparametric test.

For the purpose of the immunohistochemistry study, the tissue blocks were parafin-embedded and stained with the LSAB 2 System Horse raddish peroxidase. Positive control for Cathepsin D staining was normal tonsils and vocal cord tissue. The same tissues were used for negative control by omitting the primary antibody. The immunoanalysis was established by counting 1000 cells and the respective number of positive cells. These results was estimated by the Kruskal Wollis test. 


\section{Results}

In our study group there were 50 patients who underwent surgery for intracranial and intraspinal meningiomas. An evident female prevalence of 70\% (35 female patients) was noted as well as a high percent od primary meningiomas among our patients, accounting for $82 \%$ (41 case) of 50 cases (Table 1.).

\begin{tabular}{|c|c|c|c|}
\hline Patients & $\begin{array}{c}\text { Primary } \\
\text { meningiomas }\end{array}$ & $\begin{array}{c}\text { Recidivant } \\
\text { meningiomas }\end{array}$ & Total \\
\hline Female & 30 & 5 & 35 \\
\hline Male & 11 & 4 & 15 \\
\hline Total & 41 & 9 & 50 \\
\hline
\end{tabular}

Table 1. Sex distribution of primary and recidivant meningiomas

The average age of patients with primary meningiomas was 62 years while a sligthtly younger group had recidivant meningiomas $(59,34$ years) (Table 2.).

\begin{tabular}{|c|c|c|}
\hline Age & Primary meningioma & Recidivant meningioma \\
\hline Average age & $62(52-79)$ & $59,34(46-73)$ \\
\hline Female & $61,96(52-79)$ & $59,8(52-73)$ \\
\hline Male & $62,5(54-75)$ & $58,75(46-67)$ \\
\hline
\end{tabular}

Table 2. Age distribution of patients with meningiomas

This relation of the mean age of diagnosis of primary and recidivant desease was similar in the female and male groups of patients. The mean reccurence free interval in our group was 4,33 years ( 2 to 8 years). A total of 64 meningioma specimen have been submitted to histological analysis ( one primary meningioma was multiple, 7 tumors recurred once, 1 tumor recurred twice and 1 meningioma recurred three times). The results of the pathohistologic analysis are shown in Table 3. Most of the analysed tumors were graded as the WHO I group (57 cases). The remainder were classified as WHO II (5) and WHO III (2) (Table 3.).

\begin{tabular}{|c|c|c|}
\hline Histologic type & $\mathrm{N}$ & $\%$ \\
\hline Meningithelial & 23 & 35,9 \\
\hline Psamomatous & 9 & 14,1 \\
\hline Transitional & 15 & 23,4 \\
\hline Fibroblastic & 7 & 10,9 \\
\hline Malignant & 1 & 1,6 \\
\hline Angiomatous & 3 & 4,7 \\
\hline Atypical & 5 & 7,8 \\
\hline Papillary & 1 & 1,6 \\
\hline Total & 64 & 100 \\
\hline
\end{tabular}

Table 3. Frequency of histologic types of meningiomas

One tumor of the primary meningioma group was malignant while two were atypical. Among the recidivant meningiomas, $2(33,3 \%)$ were grade I tumors, $3(50 \%)$ eningiomas were grade II and $1(16,67 \%)$ was graded as WHO III. A detailed analysis of the histological parameters of atypical and malignant meningiomas was performed. Hypercellularity, atypia, prominent nucleoli, loss of vesicular nuclei and focal necrosis were present in $7(10,9 \%)$ cases. Architectural loss and hyperchomasia were noted in $6(9,4 \%)$ of tumors. Brain invasion and invasion of distal structures was demonstrated in 2 cases $(3,1 \%)$ respectivly. 


\section{ORIGINALNI RADOVI}

The mean mitosis count in both groups (primary and recidivant tumors) was 1 mitosis on HPF $(0,98-1,19)$. The Mann-Whitney test used to establish the relation between the mitosis count on 10 HPF in the groups of primary and recidivant meningioma, have not demonstrated any significant statistical difference. The average mitosis count on $20 \mathrm{HPF}$ in the group of primary meningiomas was 1,74 and in the group of recidivant tumors was 3,1. The number of mitoses on $20 \mathrm{HPF}$ was established by grading mitoses in groups (0-4 . 5-10, 1120 and $>20$ ) and then each group was analysed by the Mann Whitney test. The result was highly statistically significant $(\mathrm{p}<0,01)$ in the groups of primary and recidivant meningiomas (Table 4 .).

\begin{tabular}{|c|c|c|c|c|}
\hline \multicolumn{2}{|c|}{} & \multicolumn{2}{c|}{ Meningioma } & \multirow{2}{*}{ Total } \\
\cline { 3 - 5 } \multicolumn{2}{|c|}{} & Primary & Recidivant & \\
\hline \multirow{4}{*}{$\begin{array}{c}\text { Mitosis on } 20 \\
\text { HPF }\end{array}$} & $0-4$ & 40 & 17 & 57 \\
\cline { 2 - 5 } & $5-10$ & & 3 & 3 \\
\cline { 2 - 5 } & $11-20$ & 2 & 1 & 3 \\
\cline { 2 - 5 } & $>20$ & 1 & 21 & 64 \\
\hline
\end{tabular}

Table 4. The mean mitosis count of primary and recidivant meningiomas

In the recidivant meningiomas group the mitosis count on 20 HPF was higher than in the primary meningiomas group. Most of the analysed meningioma specimen (62 of 64 cases or 96,88\%) demonstrated immunopositivity to Cathepsin D. The citoplasm of benign meningiomas showed strong positivity (Picture 1.) for this marker while the intensitiy of staining decreased with the raising of the WHO grade of tumors (Table 5.).

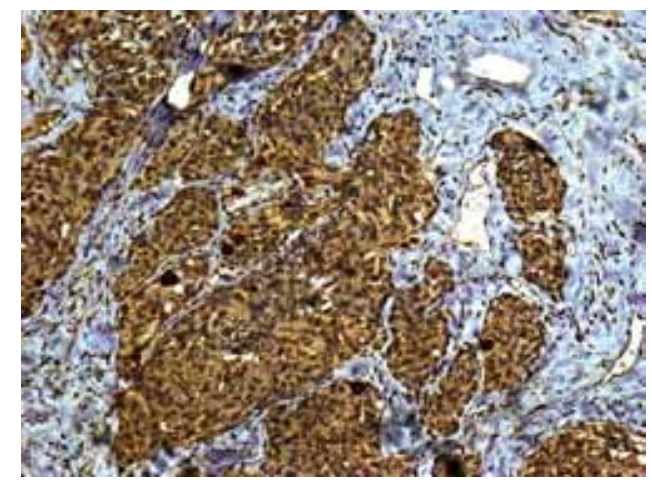

Intense diffuse cytoplasmic positivity in the meningothelial meningiomas WHO gr. I

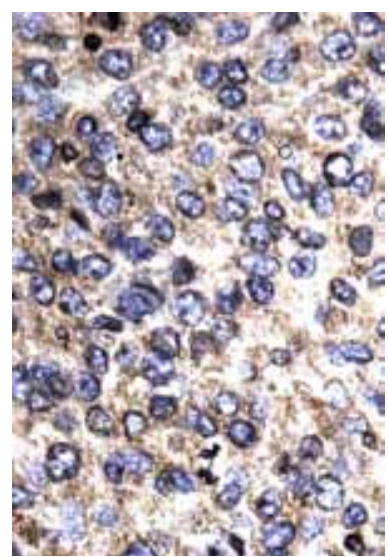

Focal immunopositivity of low intensity in the malignant meningioma WHO gr. III

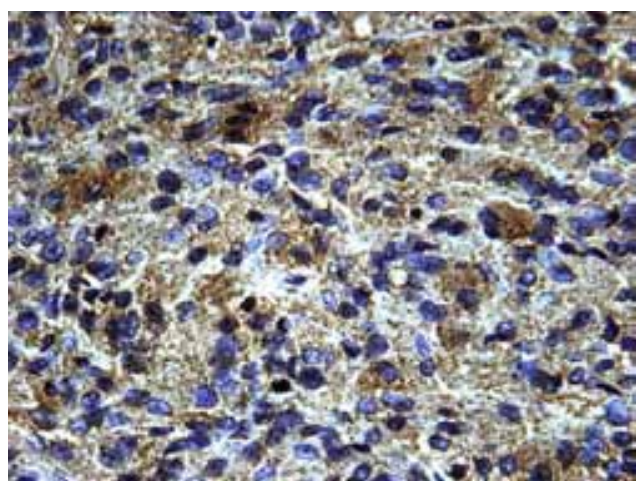

Focal cytoplasmic immunopositivity in atypical meningioma WHO gr. II

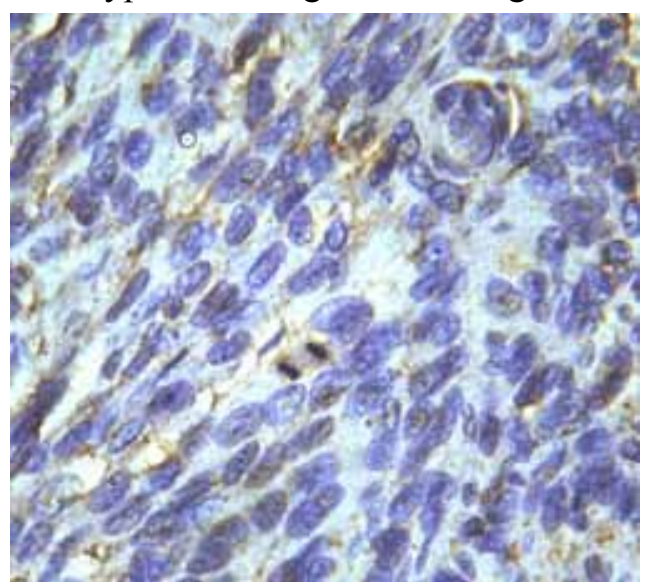

Negative expression in malignant meningioma WHO gr. III; mitosis (at center)

Picture 1. 
The greatest number of tumors reactive for Cathepsin D were graded as WHO I and immunoreactivity in those cases was focal. Tumors of a higher invasive potencial (WHO II and III) reacted with Cathepsin D in a more diffuse way but their number was significantly lower (4 of these tumors were graded as WHO II and 1 as WHO III). This relation was analysed with the Kruskal-Wollis test and a statistically high difference was demonstrated. Benign meningiomas graded as the WHO I group were more immunoreactive to Cathepsin D than tumors of higher grade $(\mathrm{p}<0,05)$. In the majority of tumors the immunoexpression was diffuse (52 case or $91,23 \%$ ), it was focal in most atypical meningiomas ( 4 cases or $80 \%$ ) and in one case of malignant meningioma the staining was absent (Table 5.)

\begin{tabular}{|c|c|c|c|c|c|c|}
\hline \multirow{2}{*}{\multicolumn{3}{|c|}{ Immunoexpression of Cathepsin D }} & \multicolumn{3}{|c|}{ Cathepsin } & \multirow{3}{*}{$\begin{array}{c}\text { Total } \\
57\end{array}$} \\
\hline & & & \multirow{2}{*}{$\begin{array}{c}\text { No staining } \\
0\end{array}$} & \multirow{2}{*}{$\begin{array}{c}\text { Focaly } \\
52\end{array}$} & \multirow{2}{*}{$\begin{array}{c}\text { Diffuse } \\
5\end{array}$} & \\
\hline \multirow{6}{*}{ WHO } & \multirow{2}{*}{ I } & $\mathrm{N}$ & & & & \\
\hline & & $\%$ & $0 \%$ & $100 \%$ & $50 \%$ & $89,06 \%$ \\
\hline & \multirow{2}{*}{ II } & $\mathrm{N}$ & 1 & 0 & 4 & 5 \\
\hline & & $\%$ & $50 \%$ & $0 \%$ & $40 \%$ & $7,81 \%$ \\
\hline & \multirow{2}{*}{ III } & $\mathrm{N}$ & 1 & 0 & 1 & 2 \\
\hline & & $\%$ & $50 \%$ & $0 \%$ & $10 \%$ & $3,13 \%$ \\
\hline \multirow{2}{*}{\multicolumn{2}{|c|}{ Total }} & $\mathrm{N}$ & 2 & 52 & 10 & $64 \%$ \\
\hline & & $\%$ & $100 \%$ & $100 \%$ & $100 \%$ & $100 \%$ \\
\hline
\end{tabular}

Table 5. Immunoexpression of Cathepsin D.

A high immunoreactivity to Cathepsin D was associated with a low mitosis count. The Kruskal Wollis test demonstrated a statistically significant difference between the immunoexpression of Cathepsin $\mathrm{D}$ and the number of mitoses on $10 \mathrm{HPF}(\mathrm{p}<0,05)$ (Table 6.) and on $20 \mathrm{HPF}(\mathrm{p}<0,05)$. Focal expression of Cathepsin D staining was present in a great number of tumors that exibited less then 4 mitoses on 10 HPF (57 cases or $98,28 \%$ of tumors with focal immunostaining). The remaining 3 cases of meningiomas graded as WHO I demonstrated a diffuse staining. Two meningiomas showing focal and diffuse immunoexpression of Cathepsin $\mathrm{D}$ were present in the WHO groups II and III respectivly.

\begin{tabular}{|c|c|c|c|c|c|c|}
\hline \multirow{2}{*}{\multicolumn{3}{|c|}{$\begin{array}{c}\text { Expression of Cathepsin D and mitoses } \\
\text { on } 10 \mathrm{HPF}\end{array}$}} & \multicolumn{3}{|c|}{ Cathepsin } & \multirow{2}{*}{ Total } \\
\hline & & & No staining & Focaly & Diffuse & \\
\hline \multirow{6}{*}{$\begin{array}{l}\text { Mitoses on } \\
10 \mathrm{HPF}\end{array}$} & \multirow{2}{*}{$0-4$} & $\mathrm{~N}$ & 0 & 57 & 3 & 57 \\
\hline & & $\%$ & $0 \%$ & $98,28 \%$ & $60 \%$ & $93,8 \%$ \\
\hline & \multirow{2}{*}{$5-10$} & $\mathrm{~N}$ & 0 & 1 & 1 & 2 \\
\hline & & $\%$ & $0 \%$ & $1,72 \%$ & $20 \%$ & $3,1 \%$ \\
\hline & \multirow{2}{*}{$11-20$} & $\mathrm{~N}$ & 1 & 0 & 1 & 2 \\
\hline & & $\%$ & $100 \%$ & $0 \%$ & $2 \%$ & $3,13 \%$ \\
\hline \multirow{2}{*}{\multicolumn{2}{|c|}{ Total }} & $\mathrm{N}$ & 1 & 58 & 5 & $64 \%$ \\
\hline & & $\%$ & $100 \%$ & $100 \%$ & $100 \%$ & $100 \%$ \\
\hline
\end{tabular}

Table 6. Expression of Cathepsin D and number of mitoses on $10 \mathrm{HPF}$.

\section{Discussion}

Meningiomas are common in everyday neurosurgical and neuropathology practice, yet their origin as well as their biological behaviour still remain a riddle. Several histologic classification have been in use but none of them, neither the newest WHO 2000 classification was completly satisfactory. In our study, a total of 50 
patients and 64 specimen of tumor were analysed. Primary meningiomas were present in 41 case $(82 \%)$ while these neoplasms were recidivant in 9 patients $(18 \%)^{1,4}$. The male - female ratio of meningioma in the literature shows a 3:1 or even 2:1 relation with a female prevalence. In our study, we noted a 2,3:1 female to male ratio. The mean age in the group of our patients was 62 years, ranging from 46 to 79 years of age. This is consistent whit the literature data ${ }^{2}$. The ability to recurre is a feature typical of meningioma, the origin of which is yet to be established. Even after a complete resetion 5\% of all meningiomas recurre in the next 5 years and $7-20 \%$ are recidivant after 20 years. Tumors graded as WHO group II are particularly intresting because $40 \%$ of these tumors shall present a recidive in the first 5 years after surgery. Several factors were taken in consideration to explain this property of atypical meningiomas and the widness of the resection margins are thought to be of extreme importance to prevent reurrence ${ }^{4}$. In our study, only 9 patients had meningioma recurrence so this number was not representative for estimation of surgical resetion margins. During the followup period of 2 years, none of the primary meningiomas have recurred. One patient with a malignant meningioma died during the work on this study.

The histological type of meningiomas in our study group were consistent whit their distribution established by other authors. The more numerous among the primary meningiomas were WHO grade I, while in the recurrent neoplasms group $50 \%$ of them were grade II (3 cases). Tumors graded as WHO II make $20 \%$ of all surgicaly removed meningiomas and are associated whit a high recurrence risk 1,3 . Atypical meningiomas were present in our study in 5(7,81\%) cases and 2 malignant meningiomas were also diagnosed $(3,21 \%)$. An important diagnostic criterion for distinguishing WHO grades I and II is increased proliferative index expressed as the number of mitosis higher than 4 on 10 consecutive high power fileds (HPF) ${ }^{9}$. The average mitosis count in our study was $1(0,98-1,19)$ in both primary and recidivant meningioma group. We established that there was a high statistically significant difference of the mitosis count on 20 HPF between the primary and recidivant meningiomas. The importance of establishing the potential of recurrence lies in the fact that those patients require a thorough postoperative follow-up ${ }^{3,9}$. Since the difference in mitosis count was significant only on consecutive $20 \mathrm{HPF}$, we suggest that more diagnostic criteria must be included in the estimation of malignancy in meningiomas whose histological caracteristics are not clear.

The role of Cathepsin D in stimulation of micrometastasis growth in breast cancer was reported in several studies $7,8,10,11$. Overexpression of Cathepsin D in invasive breast tumors facilitates the local basement membrane distruction and apoptosis inhibition ${ }^{11,12,13}$. This features are signs of a bad prognosis. Similar effects can be demonstrated in melanocytic tumors ${ }^{12}$. In a glioblastoma multiforme series the Cathepsin D expression ranged from 15 to $50 \%$ of cases ${ }^{13,14}$. A positive control can be brain stromal tissue, whose macrophages exibit a strong immunoreaction to Cathepsin D. Those cells help degradation of the extracellular matrix and myelin remnants.

Several authors have investigated the relation between the tumor grade and the Cathepsin expression. Tews 13, 14 and Sivaparvathi ${ }^{15}$, indipendently, have noted a higher reactivity to Cathepsin D in anaplastic astrocytomas and glioblastomas compared to astrocytomas of a lower grade and normal tissue. An opposite relation have been established by Warich et al ${ }^{16}$. They stated that Cathepsin D overexpression is present in astrocytomas of lower grades, rather than in high grade tumors. A different pattern of Cathepsin D expression have been found in several tumor types (astrocytomas, oligodendrogliomas, ependimomas, PNET and other tumors) by Robson and collegues ${ }^{17}$. In a study of potential prognostic markers over a series of 44 meningiomas, performed by Gottschalk et al. ${ }^{18}$, tumors were graded as grade I (whitout malignancy) to grade IV (malignant meningiomas with focal sarcomatoid component). "Some"' degree of expression was noted but without any consistent corelation with histologic grade, mitotic index and proliferative potential. The level of Cathepsin D expression was measured in a series of meningiomas and breast carcinoma by Koehors et al ${ }^{19}$. This study confirmed a certain immunoexpression but it was 2,4 times lower in the meningioma group. No corelation was found between the Cathepsin D expression and expression of estrogen and progesteron receptors, even though all these markers are encoded by the same gene ${ }^{19,20}$. The study of 86 meningiomas performed by Castilla et al..$^{22}$ confirmed a stronger expression of Cathepsin D in tumors of lower grade and lower mitotic and apoptotic potential. These results are consistent with the conclusion of our study which was confirmed with the Kruskal Wollis test $(\mathrm{p}<0,05)$. There are several earlier studies that report a higher level of 
immunoexpression of Cathepsin D in higher grade meningiomas ${ }^{16,19}$, in contrast with the results of the study performed by Castilla et al and of our study. A possible explanation of these different results can be the fact that functionally inactive Cathepsin D molecules have been stained or that there has happened a cross reaction with some other molecules that are overexpressed in higher grade tumors. A potential Cathepsin D disregulation in tumors of increasing grade could be an explanation for a weaker immunostaining in higer grade meningiomas. Since Cathepsin D exibit a strong expression in benign meningiomas, it could not be used as a prognostic factor of malignancy and invasivness. On the contrary, the loss of positive staining could be an alert for a potentialy agressive biological behaviour. Cathepsin D could be used in immunopannels as a negative marker for atypical and malignant meningiomas.

\section{Conslusion}

The socioepidemiological caracteristics of our study group are consistent whit the incidence and prevalence of meningiomas noted by other authors. There was no significant difference in the mitosis count on 10 HPF between the primary and recidivant meningiomas but this difference was highly significant $(\mathrm{p}<0,01)$ when mitoses were counted on $20 \mathrm{HPF}$. Cathepsin D positive immunostaining was present in $62(96,88 \%)$ tumors. Most of those tumors were biologicaly benign. A statistically significant difference of Cathepsin D immunostaining was found in relation with the mitoses count on $10 \operatorname{HPF}(p<0,05)$, on $20 \operatorname{HPF}(p<0,05)$ and with the tumor histological grade.

\section{Literature}

1. Markus J Rimenschneider, Arie Perry, Guido Reifenberger. Histological classification and molecular genetics of meningiomas. Lancet Neurol 2006; 5: 1045-45.

2. Saraf S, McCarthy BJ, Villano JL. Update on meningiomas. Oncologist 2001;16(11): 1604-13. Epub 2011 Oct 25.

3. David N Louis, Hiroko Ohgaki, Otmar D. Wiestler, Webster K.Cavenee. WHO classification of tumors of the central nervous system. 4th edition, International agency for research on cancer. Lyon, 2007.

4. Manivel, JC, Sung JM. Pathology of meningiomas. Clinicopathologi study of potentially aggressive variant of meningiomas. AM J Surg Pathol 1995; 19: 493-505.

5. Josephine A, Von Randow U, Shindler S, Tews DS. Expression of extracellular matrix degrading proteins in classic,atypical and anaplastic meningiomas. Pathology-Research and practice. 202 (2006) 365-372.

6. Glondu M, Coopman P, Laurent-Matha V, Garcia M, Rochefort H, Liaudet Coopman E. A mutated Cathepsin D devoid of its atalytic activity stimulates the growth of cancer cells. Oncogene 2001; 20:6920-9.

7. Glondu M, Liaudet-Coopman E, Derocq D, Platet N, Rochefort H, Garcia M. Down-regulation of cathepsin D expression by antisense gene transfer inhibits tumor growth and experimental lung metastasis of human breast cancer ells. Oncogene 2002; 21: 5127-34.

8. Berchem G, Glondu M, Gleizes M, Brouillet JP, Vignon F, Garcia M, Liaudet-Coopman E. Cathepsin D affects multiple tumor progression steps in vivo: proliferation, angiogenesis and apoptosis. Oncogene 2001; 21: 5951-5.

9. Louis DN, Scheithauer BW, Budka H, Von Deimling A, Kepes JJ,. Meningiomas: Pathology and genetics of tumors of the nervous system. In: Kleihues P, Cavenee WK, eds. World Health Organisation classification of tumors. Lyon: IARC Press, 2000: 176-84.

10. Redecker B, Heckendorf B, Grosch HW, et al. Molecular organization of the human Cathepsin D gene: DNA Cell Biol. 1991; 10: 423-341.

11. Rochefort H, Garcia M, Glondu M. Cathepsin D in breast cancer: mehanism and linical applications: a 1999 overwiew. Clin Chim Acta. 2000; 291: 157-170. 
12. Frohlich E, Schlangenhauff B, Morhle M. Activity expression and transcription rate of Cathepsins B, D, H and L in cutaneous malignant melanoma. Cancer 2001; 91: 972-982.

13. Tews DS, Nissen A. expression of adhesion factors and degrading proteins in primary and secondary glioblastoma and their precursor tumors. Invasion Metastasis. 1998-99; 18: 27-284.

14. Tews DS. Adhesive and invasive features gliomas. PatholRes Pract. 2000; 196: 710-711.

15. Sivaparvathi M, Sawaya R, Chintala SK, et al. Expression of cathepsin D during the progression of human gliomas. Neurosci Lett. 1996; 208: 171-174.

16. Warich M, Von Bossanyi P, Dietzmann K. Expression of cathepsin D in human astrocytic neoplasia. Gen DiagnPathol. 1995; 141: 93-96.

17. Robson DK, Ironside DW, Reid WA. Immunolocalization of cathepsin D in the human nervous system and central nervous system neoplasm. Neuropathil Appl Neuro-biol. 1990; 16: 39-44.

18. Gottschalk J, Goebel S, Jautzke G, et al. Influence of preoperative dexamethason therapy on proliferating cell nuclear antigen (PCNA) expression in comparison to other parameters in meningiomas. Histol Histopathol. 1992; 7: 653-661.

19. Koehorst SGA, Spapens MED, van der Kallen CJH. Progesterone receptor synthesis in human meningiomas: relation to the estrogen-induced proteins $\mathrm{pS} 2$ and cathepsin D and influence of epidermal growth factor, forskolin and phorbol ester in vitro. Int J Biol Markers. 1998; 13: 16-23.

20. Cavailles V, Augereau P, Garcia M, et al. Estrogenes and growth factors induce the mRNA of the 52 K-procathepsin D secreted by breast cancer cells. Nucleic Acid Res. 1998; 16: 1903-1919.

21. Blankenstein MA, Verheijen FM, Jacobs JM. Occurrence, regulation and significance of progesterone reeptors in human meningioma. Steroids. 2000; 65: 795-800.

22. Castilla AE, Prayson RA, Caroline M, Abramovich MC, Cohen LM. Immunohistochemical expression od Cathepsin D in Meningiomas. Am J Clin Pathol 2003; Am J Clin Pathol 2003; 119: 123-8.

Primljen 9. XII 2011.

Revidiran 13. I 2012.

Prihvaćen 28. I 2012.

Corresponding author:

dr Zorana Vukašinović Bokun

KBC Zemun, Beograd

Služba za kliničku patologiju

Vukova 9, Zemun, Beograd, Srbija email: zorana.bokun@gmail.com 